Portland State University

PDXScholar

Environmental Science and Management

Faculty Publications and Presentations

$10-2013$

\title{
Climate Change and Fire Management in the Mid- Atlantic Region
}

\author{
Kenneth L. Clark \\ USDA Forest Service \\ Nicholas Skowronski \\ USDA Forest Service \\ Heidi Renninger \\ Rutgers University - Newark \\ Robert M. Scheller \\ Portland State University, rmschell@pdx.edu
}

Follow this and additional works at: https://pdxscholar.library.pdx.edu/esm_fac

Part of the Environmental Sciences Commons, and the Forest Sciences Commons

Let us know how access to this document benefits you.

\section{Citation Details}

Clark, K. L., Skowronski, N., Renninger, H., \& Scheller, R. (2013). Climate change and fire management in the mid-Atlantic region. Forest Ecology and Management.

This Article is brought to you for free and open access. It has been accepted for inclusion in Environmental Science and Management Faculty Publications and Presentations by an authorized administrator of PDXScholar. Please contact us if we can make this document more accessible: pdxscholar@pdx.edu. 


\title{
Climate change and fire management in the mid-Atlantic region
}

\author{
Kenneth L. Clark ${ }^{\mathrm{a}, *}$, Nicholas Skowronski ${ }^{\mathrm{b}}$, Heidi Renninger ${ }^{\mathrm{c}}$, Robert Scheller ${ }^{\mathrm{d}}$ \\ a Silas Little Experimental Forest, Northern Research Station, USDA Forest Service, 501 Four Mile Road, P.O. Box 232, New Lisbon, NJ 08064, USA \\ ${ }^{\mathrm{b}}$ Northern Research Station, USDA Forest Service, 180 Canfield St., Morgantown, WV 26505, USA \\ ${ }^{\mathrm{c}}$ Rutgers University, Department of Biological Sciences, 195 University Ave., Newark, NJ 07102, USA \\ ${ }^{\mathrm{d}}$ Department of Environmental Sciences and Management, Portland State University, P.O. Box 751, Portland, OR 97207, USA
}

\section{A R T I C L E I N F O}

\section{Article history:}

Available online 19 October 2013

\section{Keywords:}

Forest composition

Wildfire

Prescribed burns

Carbon sequestration

Mitigation

\begin{abstract}
A B S T R A C T
In this review, we summarize the potential impacts of climate change on wildfire activity in the midAtlantic region, and then consider how the beneficial uses of prescribed fire could conflict with mitigation needs for climate change, focusing on patters of carbon (C) sequestration by forests in the region. We use a synthesis of field studies, eddy flux tower measurements, and simulation studies to evaluate how the use of prescribed fire affects short- and long-term forest $C$ dynamics. Climate change may create weather conditions more conducive to wildfire activity, but successional changes in forest composition, altered gap dynamics, reduced understory and forest floor fuels, and fire suppression will likely continue to limit wildfire occurrence and severity throughout the region. Prescribed burning is the only major viable option that land managers have for reducing hazardous fuels in a cost-effective manner, or ensuring the regeneration and maintenance of fire-dependent species. Field measurements and model simulations indicate that consumption of fine fuels on the forest floor and understory vegetation during most prescribed burns is equivalent to $<1-3$ years of sequestered $C$, and depends on pre-burn fuel loading and burn intensity. Overstory tree mortality is typically low, and stands have somewhat reduced daytime $\mathrm{C}$ uptake during the next growing season following burns, but may also have reduced rates of ecosystem respiration. On an annual basis, net ecosystem productivity is negative the first year when consumption losses are included, but then positive in following years, and stands can reach $C$ neutrality within $<2-3$ years. Field data and model simulations suggest that increases in prescribed burning in fire-prone areas would have little appreciable effect on long-term forest $C$ dynamics in some fire-prone forest types. Large-scale conversion to young pine plantations for fiber and biofuels will potentially increase the risk of wildfires, as had occurred previously in the late-19th and early-20th centuries in the region.
\end{abstract}

Published by Elsevier B.V.

\section{Introduction}

Wildfire occurrence and severity are driven by a variety of factors, including climate and weather conditions (Liu et al., 2013; Morton et al., 2013; Potter, 2012), fuel loading and arrangement (Agee and Skinner, 2005; Ottmar et al., 2007; Rollins, 2009), and natural and human-caused ignitions (Hawbaker et al., 2013). Climate change may have a major impact on wildfire activity (Hessl, 2011), and increases have been projected for a number of regions in North America (Liu et al., 2013). In contrast to the Western US and Canada, where changes in climate are projected to significantly increase the frequency and area burned by wildfires (Spracklen et al., 2009; Westerling et al., 2006; Wimberly and Kennedy, this issue; Wotton et al., 2010), wildfire activity has been relatively low and only moderate increases are projected for the mid-Atlantic region (Liu et al., 2013; Morton et al., 2013; NIFC,

\footnotetext{
* Corresponding author. Tel.: +1 6098940325.

E-mail address: kennethclark@fs.fed.us (K.L. Clark).
}

2013). Forest recovery following agricultural abandonment (Pan et al., 2011), successional trends towards older, more mesic, closed-canopy forests (Abrams, 2003; Little, 1979; Nowacki and Abrams, 2008), and less flammable fuel beds in the understory and litter layer (Kreye et al., 2013) have reduced wildfire size and severity considerably compared to historic fire regimes and the regional peak in the late 1800's and early 1900's (Brose et al., 2013a; Forman and Boerner, 1981; Little, 1979). Wildfire suppression activities are facilitated by the extensive road network that exists in the region (Forman and Boerner, 1981; Scheller et al., 2011), and complex spatial patterns of land use, forest ownership and forest fragmentation (Drummond and Loveland, 2010) will likely continue to constrain the spread of wildfires in the region. These factors could moderate any potential increases in enhanced fire weather conditions, drought, potential changes to forest structure and fuel loading due to insect invasions, and other stresses associated with climate change in the mid-Atlantic region.

In addition to direct suppression activities, prescribed fire is the primary management practice used by agencies to mitigate 
wildland fires in the mid-Atlantic region. Prescribed burning is the most cost-effective method for reducing hazardous fuels in areas such as the New Jersey Pinelands National Reserve, where it has been used for this purpose since the late 1930's (Clark et al., 2009; Little and Moore, 1949; NJFFS, 2006). More recently, prescribed fire use has been expanded to restore historic fire regimes and encourage the regeneration of canopy oaks (Quercus spp.) and other fire-tolerant species in the region (Arthur et al., 2012; Brose et al., 2013b; Hutchinson et al., 2012). Benefits of reintroducing fire on the landscape for the maintenance of biodiversity are wellestablished (e.g., Fan et al., 2012; Jordan et al., 2003; Phillips et al., 2012). In some forests, early-successional species are largely dependent on the occurrence of frequent, low intensity fires (Burton et al., 2011; Jordan et al., 2003), prompting efforts for the reintroduction of fire on forested landscapes throughout the mid-Atlantic (Nowacki and Abrams, 2008; Phillips et al., 2012). However, a more liberal "let it burn" policy for wildland fire use cannot be considered a viable management option in the region, because of high population densities, proximities to urban population centers, the extent of wildland urban interface (WUI) areas, legal liability issues, aesthetic concerns and the emissions of fine particulates (PM 2.5) and other pollutants in or near nonattainment areas (Urbanski, 2014).

Wildland fire management strategies, including a suppressiononly strategy, are directly linked to the storage of carbon (C) on the landscape, and can affect the emissions of carbon dioxide $\left(\mathrm{CO}_{2}\right)$ and other greenhouse gasses, leading to potential feedbacks with climate change (Urbanski, 2014, Weise and Wright, 2014). Forests will continue to play a key role in C storage and sequestration throughout the region (He et al., 2012; Pan et al., 2011; Woodall et al., 2013), and obvious conflicts exist between the use of prescribed fire and the management of forests to mitigate climate change by maximizing rates of $\mathrm{C}$ sequestration (e.g., Loehman et al., 2014). For example, a prescribed fire will result in a shortterm flux of $\mathrm{CO}_{2}$ and other greenhouse gasses to the atmosphere during fuel combustion, as well as reduced rates of $C$ sequestration during stand recovery, but may prevent the occurrence of a highintensity wildland fire that would result in a much greater alteration to $\mathrm{C}$ pools and longer-term impacts to forest productivity. Forest managers will likely be required to formally evaluate the trade-offs between the short- and long-term impacts of fire management strategies on both forest $\mathrm{C}$ pools and sequestration rates in the near future. Therefore, a better understanding of the overall spatial and temporal effects of fire management in the mid-Atlantic is critical for maximizing the benefits of fire for hazardous fuel reduction, maintaining biodiversity, and ecosystem functioning, while minimizing impacts on long-term rates of $C$ sequestration to mitigate climate change.

Research efforts in eastern forests indicate that prescribed burning has relatively minor effects on overstory tree mortality (Hutchinson et al., 2005, 2012; Skowronski et al., 2007; Stephens et al., 2012), and aboveground biomass (Chiang et al., 2008). Single and repeated prescribed burns can reduce sapling and seedling density, but also can have the desired effect of stimulating regeneration of fire-tolerant species, depending on fire intensity and seasonality (Brose, 2010; Brose et al., 2013b; Hutchinson et al., 2012; Waldrop et al., 2010). Several studies have illustrated that initial consumption losses from the forest floor and understory vegetation total less than $5 \mathrm{Mg} \mathrm{C} \mathrm{ha}^{-1}$ during prescribed fires, after which C storage in vegetation is not strongly affected (Boerner et al., 2008; Clark et al., 2009, 2010a; Chiang et al., 2008; Skowronski et al., 2007). Little appreciable long-term effects on forest floor mass, coarse wood or standing dead trees have been observed in a number of studies in oak-dominated stands (Boerner et al., 2009; Hartman, 2004; Polo et al., 2013; Waldrop et al., 2010). Litter layer composition may change through time with repeated burning, resulting in a reduction in fine litter and an increase in woody fuels (Hartman, 2004; Waldrop et al., 2010). Prescribed burning also has little effect on soil organic matter and nitrogen (N) content (Boerner et al., 2009; Hubbard et al., 2004; Nave et al., 2011; Neill et al., 2007; Wang et al., 2012), unless burns are conducted very frequently (Williams et al., 2012). Decreases in soil microbial biomass and microbial $\mathrm{N}$ can occur following burning, leading to reduced $\mathrm{N}$ mineralization (Gray and Dighton, 2009; Wang et al., 2012), but in other studies little effect of burning on soil microbial properties has been reported, even under frequent burning treatments (Williams et al., 2012). The short-term effects prescribed fires on ecosystem $\mathrm{CO}_{2}$ flux immediately following prescribed fires, and the longer-term impacts of fire management on rates of $C$ sequestration are not as well characterized. In this review, we use the results of climate simulations, field measurements of fuel loading and consumption, net exchange of $\mathrm{CO}_{2}$ measured from flux towers before and after prescribed burn treatments, and model simulations to evaluate current and future uses of prescribed fire in the mid-Atlantic. We focus on the trade-offs between hazardous fuel reduction and $C$ sequestration in wildfire-prone forest types, and extend some of our conclusions to the use of prescribed fire to restore historic fire regimes in oakdominated stands in the region. Our objectives are: (1) to summarize the effects of projected climate change on wildfire activity in the mid-Atlantic over the next 50 years, and highlight some of the uncertainties with current projections, and (2) to evaluate the potential short- and long-term impacts of fire management activities on forest $\mathrm{C}$ dynamics in selected forest types in the mid-Atlantic region.

\section{Regional description and background}

The mid-Atlantic region includes four physiographic provinces; Coastal Plain, Piedmont, Ridge and Valley, and Plateau. Interactions between climate, geology, and geologic history have led to high species diversity in the region, with tree diversity alone totaling at least 135 species (www.fia.gov; Prasad et al., 2011). Dominant forest types are oak-hickory, N. hardwood, mixed pine and oakpine (Phillips et al., 2012; www.fia.gov). Forests currently cover $64 \%$ of the mid-Atlantic, and are concentrated in western Virginia, eastern W. Virginia, northwestern Pennsylvania, portions of southern and northern New Jersey, and southern and eastern New York. Nearly all large contiguous tracts of forest contain too many roads to be considered wilderness, although some areas are $>90 \%$ forested. Changes from historic fire regimes and regeneration following extensive deforestation in the 1800's are having profound effects on forest structure and composition throughout the midAtlantic (Brose et al., 2013a; Forman and Boerner, 1981; Nowacki and Abrams, 2008; Phillips et al., 2012). Fire suppression activities, in concert with intense grazing pressure by white-tail deer (Odocoileus virginianus) (Nuttle et al., 2013), defoliation by Gypsy moth (Lymantria dispar L.), changes in gap dynamics (Buchanan and Hart, 2012; Nuttle et al., 2013) as well as other factors, have reduced the regeneration of oaks and other fire-tolerant species, and is favoring the regeneration of more mesic species across the region (e.g., Abrams, 2003; Royse et al., 2010; Woodall et al., 2013). Many of the resultant closed-canopy forests have relatively low understory biomass, high fine litter turnover rates (Piatek et al., 2010), and low surface fuel loads (Graham and McCarthy, 2006; Waldrop et al. 2007) consisting of less flammable litter (Kreye et al., 2013).

Pine-dominated, oak-pine, and to a lesser extent oak-hickory forests continue to be the most wildfire prone forests in the midAtlantic, and are typically the focus of fire management activities. New Jersey and Virginia currently have the highest number of wildfire ignitions, and Virginia, W. Virginia, and New Jersey have 
the greatest areas burned annually by wildfires, averaging $14.7 \pm 11.3,8.6 \pm 4.6$, and $5.7 \pm 7.6 \mathrm{~km}^{-2}$ year $^{-1}$, respectively, from 2001 to 2010 (NIFC, 2013). Nearly all wildfires in mid-Atlantic region are caused by humans; from 2001 to 2010, lightning caused an average of only $2.1 \%$ of all wildfire ignitions in the region, and accounted for only $7.8 \%$ of acres burned in wildfires (NIFC, 2013). Wildfire occurrence in the mid-Atlantic typically peaks in spring and secondarily in fall. Precipitation occurs in all months, and wildfire activity is linked to variation in daily precipitation and the passage of strong cold fronts from northwest, when mean wind speeds tend to be higher and relative humidity lower (Fig. 1; Lafon and Quiring, 2012; Pollina et al., 2013). Higher wind speeds, relatively high atmospheric vapor pressure deficits, and high amounts of available energy on the forest floor during leafless periods result in high evaporative demand and rapid drying of surface fuels (Fig. 1a-e), especially when associated with the penetration of dry, stratospheric air following strong cold fronts (Clark et al., 2012; Pollina et al., 2013). Heilman and Bian (2010) have shown a positive link between atmospheric turbulence, expressed as turbulent kinetic energy (TKE), and erratic fire behavior during wildfires in the mid-Atlantic. The spring peak in wildfire activity also corresponds to the seasonal depression in moisture content of pitch pine (Pinus rigida Mill.) foliage in the spring (Grima, 2009; Fig. 1f). Prescribed fires in the mid-Atlantic averaged $74 \%$ of total area burned in wildfires from 2001 to 2010, and are typically dormant-season burns conducted in the late winter and early spring. The greatest number of prescribed burns are conducted in New Jersey $\left(112 \pm 50\right.$ year $\left.^{-1}\right)$, and New Jersey is second in the mid-Atlantic for area burned in prescribed fires behind Virginia, totaling $10.4 \pm 6.2$ and $13.4 \pm 6.4 \mathrm{~km}^{2}$ year$^{-1}$, respectively (NIFC, 2013).

\section{Climate scenarios and future wildfire occurrence}

Liu et al. (2013) used dynamically downscaled climate data from North American Regional Climate Change Assessment Program based on projections using the Hadley Center Climate Model (HadCM3) A2 emission scenario to predict seasonal changes in maximum daily temperature, precipitation depth, and the Keetch-Byran drought index (KBDI), computed based on daily precipitation and maximum temperature. Changes in seasonal maximum air temperature, precipitation and KBDI were mapped on a 0.5 degree grid for 2000-2060 in the mid-Atlantic region (Liu et al., 2013; Miniat et al., this issue). Projected changes in maximum temperature are highest during the summer months, although fall and winter average temperatures also show an increase. Precipitation is projected to increase along the coast during
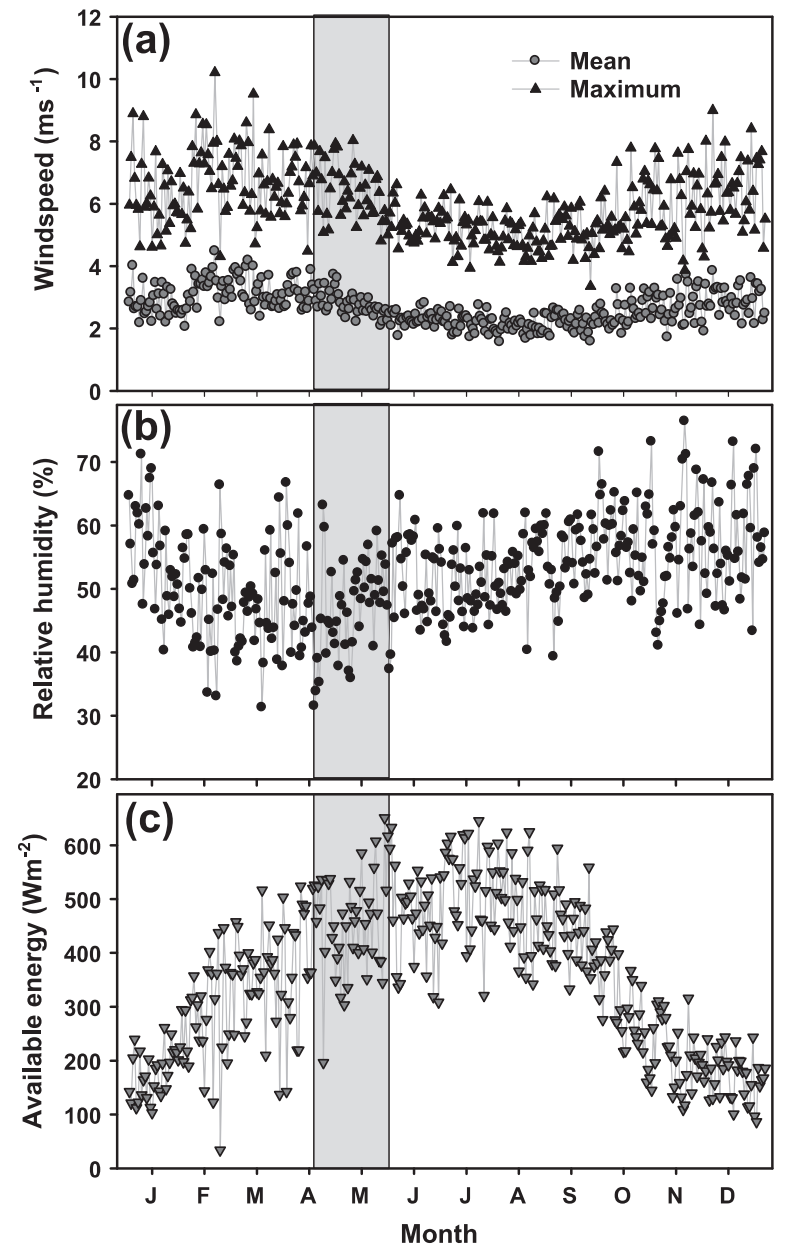

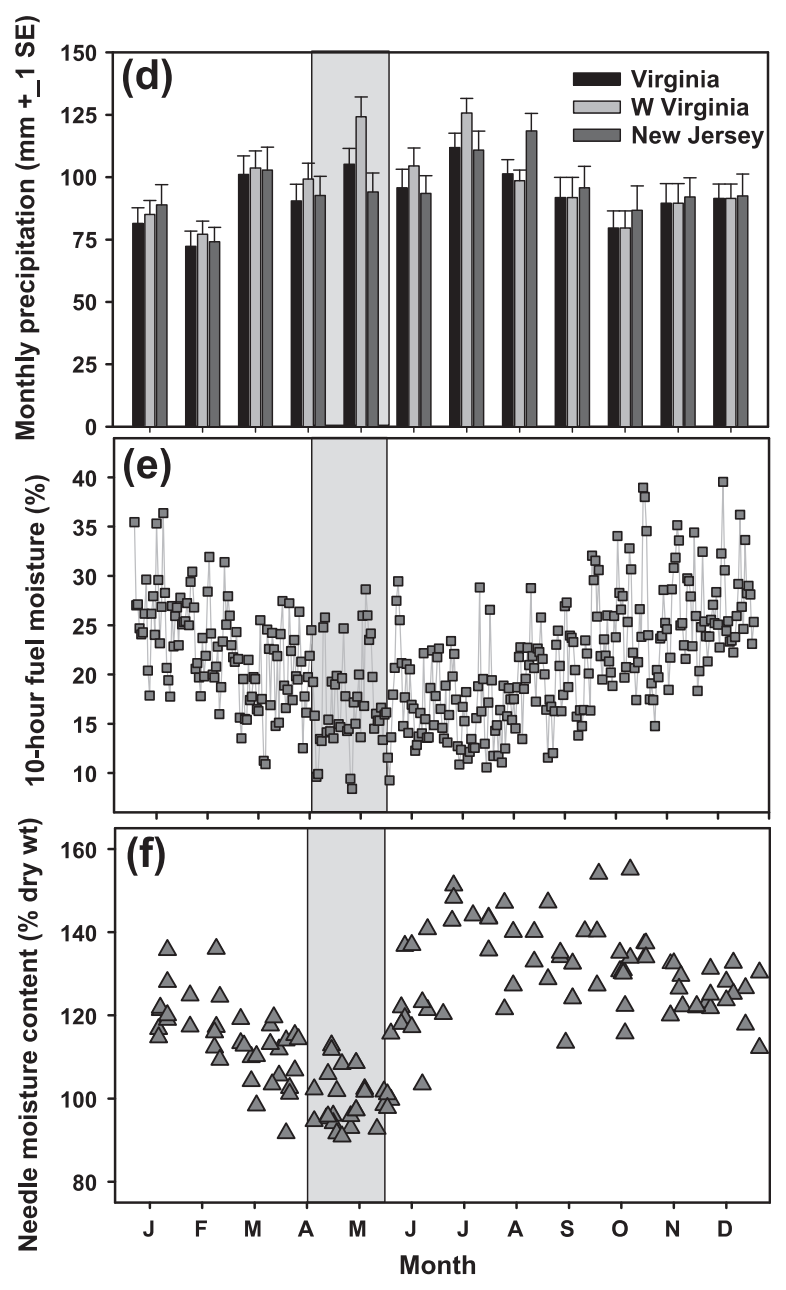

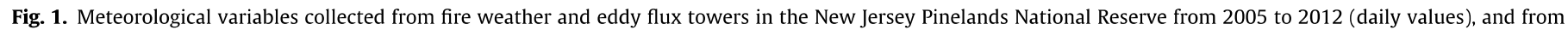

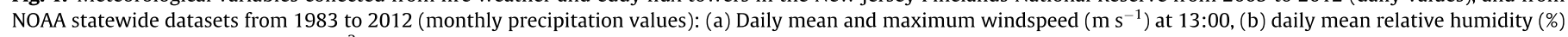

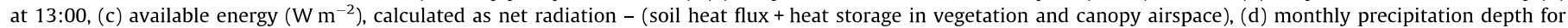

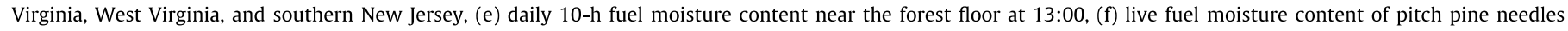
collected at two sites in the New Jersey Pinelands (\% of dry mass; USFS, pers. comm.). Shaded areas indicate the period of greatest incidence of wildfires in the region. 
all seasons, but areas in Pennsylvania are projected to be drier in spring through fall, and West Virginia is drier during the fall. KBDI is projected to change little during the spring wildfire season, and increases significantly across the region during the summer and fall.

A number of variables which play major roles in the occurrence of wildfires in the mid-Atlantic are not captured by current climate change projections (e.g., Fig. 1). For example, higher atmospheric humidity levels have been predicted for the northern and coastal portions of the region (Anderson et al., 2010). Any changes in tropical storm activity in the N. Atlantic basin, which will affect summer and fall precipitation and fuel moisture contents across the region (e.g., Lafon and Quiring, 2012), are difficult to predict with any accuracy. To begin to resolve some of these uncertainties in climate change projections, Scheller et al. (2012) coupled the HadCM3 A2 emissions scenario with the Dynamic Fire and Fuel System (Sturtevant et al., 2009) and appropriate fuel and fire behavior models (Scott and Burgan, 2005) to understand the potential impact that future climate would have on wildfire spread or fire severity in the New Jersey Pinelands. They predicted little change in wildfire severity or area burned, because of somewhat higher spring and summer precipitation, and fewer prolonged droughts later in their simulations, despite increases in air temperature. Scheller et al. (2012) suggested that only substantial changes in the climatic conditions shown in Fig. 1 would likely create conditions leading to significantly greater wildfire activity in the Pinelands.

\section{Fire management, forest productivity, and mitigation needs}

Prescribed fire use poses similar challenges for forest managers in the mid-Atlantic region as in other wildfire-prone areas, where tradeoffs exist between conducting hazardous fuel reduction treatments and wildfire risk. In the absence of major increases in wildfire activity, prescribed fire use will also be the major viable, costeffective alternative managers have for promoting the positive benefits of fire for maintaining biodiversity and ecosystem functioning in the region. However, in addition to weather and financial constraints, high population densities and the close proximity of non-attainment areas for fine particulates (PM 2.5), ozone, and other pollutants can further limit the ability of managers to conduct prescribed burns (Clark et al., 2010a; Ryan et al., 2013; Urbanski, 2014). In the future, it will be necessary for forest managers to carefully manage smoke emissions, and they will likely be required to evaluate impacts of fire use on $\mathrm{CO}_{2}$ emissions and rates of $\mathrm{C}$ sequestration by forests following prescribed burns. In the following section, we review current and future estimates of $C$ sequestration by the major forest types, estimate rates of $C$ release during prescribed burn treatments, and consider how fire management activities potentially affect current and future forest $C$ dynamics in wildfire-prone areas in the mid-Atlantic region.

The ability of forests to sequester $C$ and provide other ecosystem services is contingent upon past land use and disturbance history (Amiro et al., 2010; Kasischke et al., 2013), stand age (Pan et al., 2011), and management activities (Bracho et al., 2012; Noormets et al., 2012). Since agricultural abandonment, regenerating forests in the mid-Atlantic have been moderate to strong sinks for atmospheric $\mathrm{CO}_{2}$ (Jenkins et al., 2001; Pan et al., 2006, 2009, 2011). Overall sink strength will likely decline slowly as stands age across the region (Pan et al., 2011; Medvigy et al., 2012; Scheller et al., 2012), with productivity declining more rapidly for conifer-dominated than hardwood-dominated stands (He et al., 2012). Current forest disturbance rates are relatively low in the mid-Atlantic compared to other regions in the US (Woodall et al., 2013), and are driven primarily by wind damage (Vanderwel et al., 2013) and secondarily by insect damage (Clark et al., 2010a; Hicke et al., 2012; Medvigy et al., 2012), and forest harvesting. At the regional scale, estimates of forest productivity based on FIA data are consistent with predictions from several process-based models (Jenkins et al., 2001; Miao et al., 2011; Pan et al., 2006, 2009, 2011; Table 1). Estimates of net primary production (NPP) and net ecosystem production (NEP) for modal age forests (60-90 years old) across the region are highest for oak - hickory stands and lowest for pine-dominated stands (Table 1). When averaged across all stand types in the mid-Atlantic, current annual NEP estimates range from 1.2 to $1.6 \mathrm{Mg} \mathrm{Cha}^{-1}$ year $^{-1}$ in undisturbed stands, and 1.6 to $1.9 \mathrm{Mg} \mathrm{C}^{-1}$ year $^{-1}$ in stands recovering from disturbance, depending upon $\mathrm{N}$ and ozone deposition scenarios (Pan et al., 2009). NEP estimates derived from process-based models and FIA data are consistent with eddy flux measurements in oak-pine and pine-dominated stands in the $\mathrm{NJ}$ Pinelands (Pan et al., 2006; Clark et al., 2010b, unpubl. data; Table 1), and we use all three sources for baseline, pre-fire estimates of productivity for selected stands.

Accurate $\mathrm{C}$ accounting during wildfires or prescribed burns requires an estimation of the amount of fuel consumed, either derived from pre- and post-burn $\mathrm{C}$ pools from field measurements (Keane, 2013; Ottmar et al., 2007; Weise and Wright, 2014), fuel loading models (French et al., 2011; Lutes et al., 2009; Scott and Burgan, 2005), and/or remote sensing techniques (Skowronski et al., 2007, 2011). A number of studies have quantified fuel loading specifically for mid-Atlantic forest types before prescribed fires were conducted (e.g., Brose, 2009; Clark et al., 2009, 2010b; Skowronski et al., 2011; Wright et al., 2007). Recently-developed fuel and fire effects models are appropriate for forests in the region (Lutes et al., 2009; Scott and Burgan, 2005), and have been used to simulate $C$ losses during prescribed burns and wildfires (Scheller et al., 2011). Fine litter and $1-\mathrm{h}+10$-h woody fuels on the forest floor, which comprise the majority of fuels consumed in prescribed fires, are in a near steady-state condition in many forest across the region, because litterfall production approximately equals decomposition (Graham and McCarthy, 2006; Waldrop et al., 2007). Fewer studies have measured fuel consumption during prescribed fires in forest types characterizing the mid-Atlantic (Clark et al., 2009 2010a; Hartman, 2004; Waldrop et al., 2010). In the Fire and Fuels Surrogate (FFS) study, Waldrop et al. (2010) reported that prescribed fires reduced fine fuels on the forest floor by approx.

Table 1

Estimates of net primary production (NPP, $\mathrm{Mg} \mathrm{C}$ ha $^{-1}$ year $^{-1}$ ) and net ecosystem production (NEP, $\mathrm{Mg} \mathrm{C} \mathrm{ha}^{-1}$ year $^{-1}$ ) for selected forest types in the mid-Atlantic region. Data are derived from FIA forest inventories, PnET CN simulations, and eddy flux towers, and represent the modal age class for each forest type across the region.

\begin{tabular}{|c|c|c|c|c|}
\hline Variable & Oak - pine & Mixed pine & Oak - hickory & Source \\
\hline \multicolumn{5}{|c|}{$N P P\left(M g C h a^{-1}\right.$ year $\left.^{-1}\right)$} \\
\hline FIA data & $4.2 \pm 0.5$ & $3.8 \pm 0.6$ & $4.6 \pm 0.5$ & www.fia.gov \\
\hline PnET CN model & $4.3 \pm 0.3$ & $3.6 \pm 0.4$ & $5.0 \pm 0.5$ & Pan et al. $(2009,2011)$ \\
\hline \multicolumn{5}{|c|}{$\operatorname{NEP}\left(M g C h a^{-1}\right.$ year $\left.^{-1}\right)$} \\
\hline FIA data & $1.2-1.7$ & $1.0-1.6$ & $1.7-2.1$ & Pan et al. (2011) \\
\hline Eddy flux tower & $1.0-1.9$ & $1.6-2.0$ & - & Clark et al. (2010b) \\
\hline
\end{tabular}




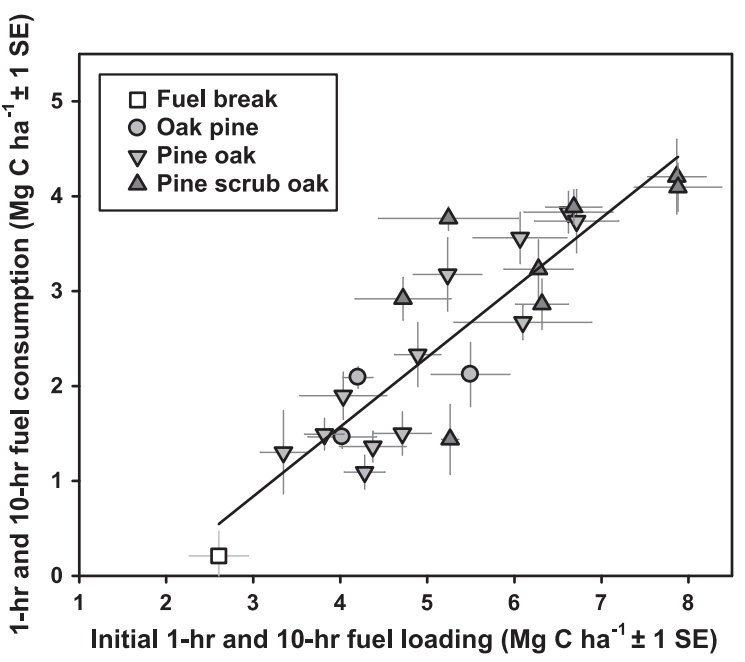

Fig. 2. The relationship between initial $1-\mathrm{h}+10$-h fuel loading and amount of fuel consumed by forest type during 24 prescribed fires conducted in the Pinelands National Reserve in 2004-2011. Consumption of $1-\mathrm{h}+10-\mathrm{h}$ fuels $=0.734$ (initial loading) $-1.364, r^{2}=0.764, F=75.37, P<0.001$ (from Clark et al. (2010a)).
$3 \mathrm{Mg} \mathrm{C}$ ha $^{-1}$ ( $80 \%$ of the total loading), while little change occurred to 1-h, 10-h and 100-h fuels. Clark et al. (2009, 2010a) estimated that consumption of litter and $1-\mathrm{h}+10$-h fuels during 24 operational prescribed fires conducted in the New Jersey Pinelands was a strong function of initial fuel loading on the forest floor, and averaged $2.9 \pm 1.5 \mathrm{MgC} \mathrm{ha}^{-1}$ loss across a range of fuel loadings and forest types (Fig. 2). In both studies, consumption losses represent ca. 2 years of sequestered $C$, assuming a NEP of $1.5 \mathrm{t} \mathrm{Mg} \mathrm{C} \mathrm{ha}^{-1}$ year $^{-1}$ for annual landscape-scale $C$ sequestration (Table 1). Pre- and post-burn LiDAR acquisitions, calibrated with field plots, have also been used to estimate consumption of understory vegetation during single and repeated prescribed burns (Skowronski et al., 2007; Clark et al., 2009). In larger prescribed fires, MODIS fireline intensity and radiant energy flux may be appropriate for estimating combustion losses, although most fires would be too small to detect reliably.

Following prescribed burns, recovery of NEP and evapotranspiration $(\mathrm{Et})$ are strongly linked to the retention and subsequent expansion of leaf area and foliar N content (Clark et al., 2012; Pan et al., 2004; Reich, 2012). If significant crowning occurs, leaf area is consumed and overstory litterfall can be reduced during the year of the burn, whereas crown scorching reduces live foliage mass and

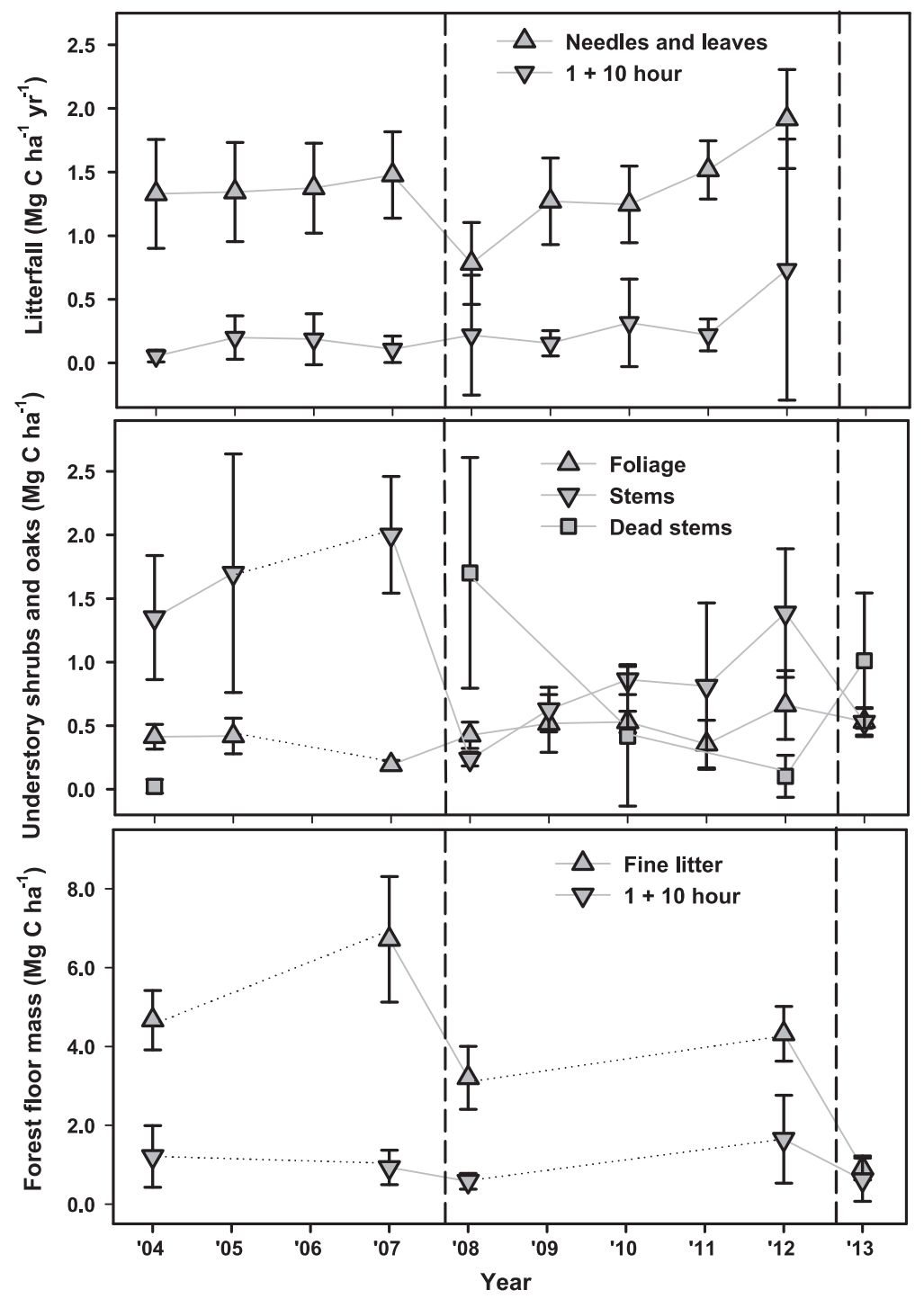

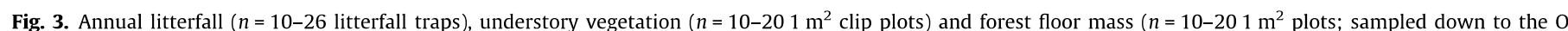

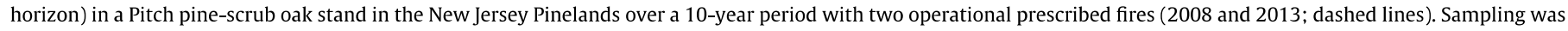
conducted in census plots within $250 \mathrm{~m}$ of the carbon flux tower. All values are means \pm 1 SD. Details of the site are in Clark et al. (2010, 2012). 
shifts the timing of litterfall to earlier in the season (e.g., Fig. 3). In some pine- and oak-dominated stands, leaf area can recover rapidly following fires because of epicormic budding, such as in stands dominated by pitch and shortleaf pine (Pinus echinata Mill.), and rapid resprouting of oaks and understory shrubs. Dormant season burns in mixed-oak stands can have minimal effect on canopy leaf area during the following growing season, or litterfall totals by the end of the growing season (Boerner et al., 1988; Hubbard et al., 2004). A variety of remote sensing techniques are available to forest managers to assess rates of leaf area recovery, including NDVI estimates from LANDSAT and MODIS imagery (e.g., Pan et al., 2006), and LiDAR techniques (Skowronski et al., 2011).

Following initial consumption losses of fine fuels on the forest floor, forest floor mass can recover to pre-burn levels relatively rapidly, depending on burn intensity (Boerner et al., 2008; Hartman, 2004; Waldrop et al., 2010). Hartman (2004) documented minimal changes to total forest floor mass, but a decrease in fine litter and an increase in 1-h, 10-h and 100-h fuels over a five-year period with two, three, or five prescribed fires conducted in oak-hickory and oak-pine stands. Boerner et al. (2008) reported that forest floor $C$ returned to pre-burn levels within 2 years following a prescribed burn in an oak-hickory stand in the FFS study. Waldrop et al. (2010) reported that fine fuel mass had recovered to pre-burn levels after 3 years, while little change occurred to 1-h, 10-h and 100-h fuels during two prescribed fires conducted over a 6 years period in an oak-hickory stand. The effects of repeated prescribed burning over a ten-year period in a pine-dominated stand in the NJ Pinelands are consistent with results from the FFS study (Boerner et al., 2008; Waldrop et al., 2010; Fig. 3). Total fuel loading (litter, $1-\mathrm{h}, 10-\mathrm{h}, 100-\mathrm{h}$, and shrubs and understory oaks) was $10.3 \pm 1.5 \mathrm{Mg} \mathrm{C} \mathrm{ha}^{-1}$ before the first burn conducted in March 2008, and 7.4 $\pm 0.8 \mathrm{Mg} \mathrm{C}^{-1}$ before the second burn conducted in March 2013. Total fuel loading was $6.0 \pm 1.4$ and $2.2 \pm 0.4 \mathrm{MgCha}^{-1}$ immediately after each burn, indicating consumption losses of 4.3 and $5.2 \mathrm{MgCha}^{-1}$, respectively. In the first prescribed burn, some crown consumption occurred, and fine litterfall from the overstory during the following growing season was reduced, after which no effects on overstory litterfall amounts were observed. Prescribed burning killed a large majority of aboveground stems of shrubs and scrub oaks but did not consume them, and understory leaf area recovered rapidly to pre-burn values during the following growing season (Fig. 3). Inputs of fine and woody litter to the forest floor were similar to pre-burn levels the year following the burn, but resulted in a slightly reduced accumulation rate of fine litter, possibly because of higher decomposition rates. Overall, results from a number of studies documenting the effects of prescribed fires conducted in mid-Atlantic forest types suggest that $\mathrm{C}$ pools on the forest floor and in understory vegetation can recover relatively rapidly following initial consumption losses.

In the few prescribed burns conducted at carbon flux tower sites, daytime and nighttime rates of net $\mathrm{CO}_{2}$ exchange have recovered rapidly following each burn (Clark et al., 2010a,b, Whelan et al., 2013). For example, half-hourly daytime NEP at near-full sunlight conditions averaged $79 \%$ of pre-burn fluxes during the summer growing season (July-August) following spring burns in the New Jersey Pinelands (Fig. 4, and Table 2). Following initial combustion losses, ecosystem respiration was reduced immediately after the burn, and during the following growing season was similar to pre-burn periods for two of the three fires (Table 3). Using BiomBGC to simulate the effects of prescribed fires in the $\mathrm{NJ}$ Pinelands, Miao et al. (2011) suggested that decreased ecosystem respiration was due to lower litter and forest floor mass following fires, reducing decomposition. If prescribed burns are hot enough to cause crown scorch of pines, then foliar respiration will also be reduced (Renninger et al., 2013; Whelan et al., 2013; Table 3). On an annual time scale, pre-burn annual NEP at the

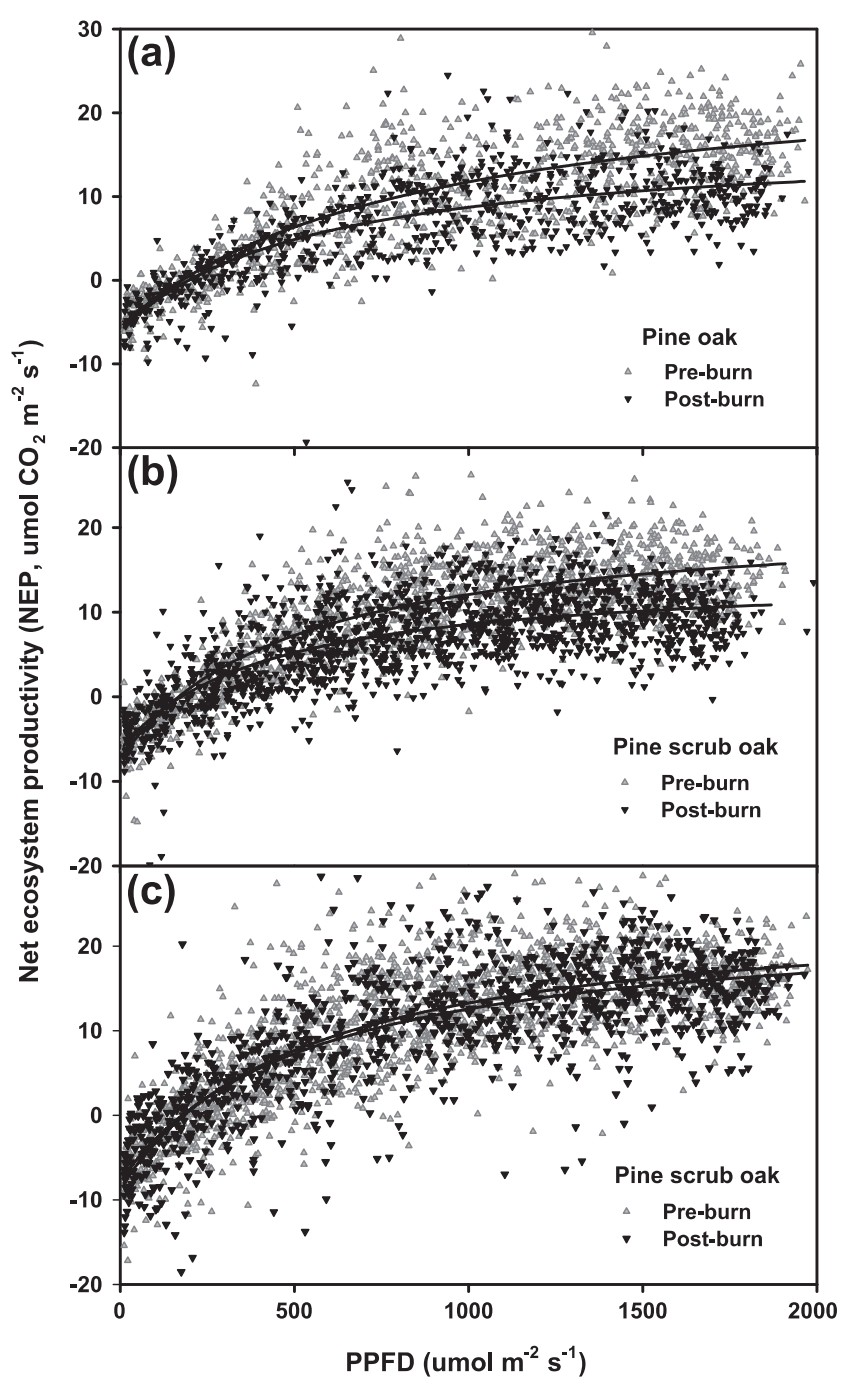

Fig. 4. Net ecosystem production measured from carbon flux towers pre- and postprescribed fire in oak-pine and pine-scrub oak stands in the New Jersey Pinelands. Data are daytime NEP in the summer (June 1-August 31), and are plotted against incident light (PPFD; $\mu \mathrm{mol} \mathrm{m}^{-2} \mathrm{~s}^{-1}$ ). Details of each site and data processing procedures are in Clark et al. (2010b, 2012).

Table 2

Coefficients for the relationship between incident light (PPFD, $\mu \mathrm{mol} \mathrm{m}^{-2} \mathrm{~s}^{-1}$ ) and net ecosystem production $\left(\mu \mathrm{mol} \mathrm{CO} \mathrm{Cm}^{-2} \mathrm{~s}^{-1}\right.$ ) from June 1 to August 31 pre- and postburn at pine-oak and pine-scrub oak stands in the New Jersey Pinelands shown in Fig. 4. Data were fit to $-\mathrm{NEP}=\left(\alpha \mathrm{PPFD} F_{\max } / \alpha \mathrm{PPFD}+F_{\max }\right)-R$. All models are significant at $P<0.0001$. Data are from Clark et al. (2010a), unpubl. data.

\begin{tabular}{|c|c|c|c|c|c|}
\hline Site/year & $\alpha$ & $F_{\max }$ & $R$ & $r^{2}$ & $F$ \\
\hline \multicolumn{6}{|c|}{ a. Pine - oak stand burned in 2006} \\
\hline Pre-burn & $0.038 \pm 0.002$ & $31.70 \pm 0.73$ & $5.61 \pm 0.28$ & 0.651 & 921 \\
\hline Post-burn & $0.042 \pm 0.002$ & $22.85 \pm 0.40$ & $6.06 \pm 0.27$ & 0.607 & 566 \\
\hline \multicolumn{6}{|c|}{ b. Pine - scrub oak stand burned in 2008} \\
\hline Pre-burn & $0.059 \pm 0.003$ & $29.09 \pm 0.39$ & $7.34 \pm 0.27$ & 0.718 & 1853 \\
\hline Post-burn & $0.051 \pm 0.004$ & $20.93 \pm 1.30$ & $6.28 \pm 0.29$ & 0.555 & 994 \\
\hline \multicolumn{6}{|c|}{ c. Pine - scrub oak stand burned in 2013} \\
\hline Pre-burn & $0.064 \pm 0.004$ & $33.47 \pm 0.51$ & $8.64 \pm 0.36$ & 0.665 & 1794 \\
\hline Post-burn & $0.058 \pm 0.004$ & $31.36 \pm 0.80$ & $7.76 \pm 0.34$ & 0.607 & 861 \\
\hline
\end{tabular}

pine-dominated stand shown in Figs. 3, 4b and 5 averaged $1.8 \mathrm{t} \mathrm{C} \mathrm{ha}^{-1}$ year $^{-1}$ before the burn, $26 \%$ of pre-burn values the year of the burn, $47 \%$ the first year following the burn, and was then similar to pre-burn periods during the second year following the 
Table 3

Eddy covariance measurements of half-hourly nighttime NEP and evapotranspiration for pre- and post-prescribed burn periods during the summer (June 1-August 31) at pine-oak and pine-dominated stands in the NJ Pinelands. Post-burn values are the summer following spring prescribed burns. Values are means \pm 1 SD.

\begin{tabular}{lllll}
\hline \multirow{2}{*}{ Stand } & \multicolumn{2}{l}{ Night time NEP $\left(\mu \mathrm{mol} \mathrm{CO}_{2} \mathrm{~m}^{-2} \mathrm{~s}^{-1}\right)$} & & \multicolumn{2}{c}{${\text { Evapotranspiration }\left(\mathrm{mm} \mathrm{day}^{-1}\right)}^{ }$} & Pre-burn & Post-burn & & Pre-burn & $2.4 \pm 0.9$ \\
\cline { 2 - 5 } & $-4.6 \pm 1.7$ & $-4.2 \pm 1.9$ & $3.3 \pm 1.2$ & $3.2 \pm 0.9$ \\
Pine-oak & $-5.0 \pm 3.0$ & $-4.9 \pm 2.1$ & $3.8 \pm 1.4$ & $3.8 \pm 1.4$ \\
Pine-scrub oak & $-7.8 \pm 5.1$ & $-8.1 \pm 3.7$ & $4.3 \pm 1.3$ & \\
\hline
\end{tabular}

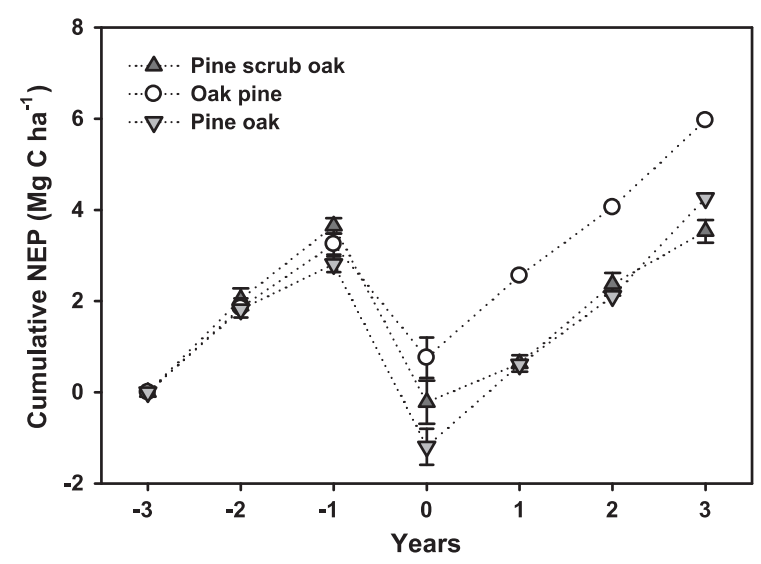

Fig. 5. Synthesis of measured and modeled sequences of NEP before, during and following prescribed fires in pine-dominated, oak-dominated, and mixed stands in the New Jersey Pinelands. Consumption losses were estimated from field data collected at each burn (e.g., Fig. 2; means $\pm 1 \mathrm{SE}$ ). Pre- and post-burn values with error bars are from gap-filled annual flux measurements of $\mathrm{NEE}_{\mathrm{c}}$ (Clark et al., 2010b, unpubl. data) and simulated values are from BiomBGC (adapted from Miao et al. (2011)).

burn (Clark et al., 2010b, unpubl. data., triangle symbols in Fig. 5). Despite consumption losses towards the high end of the range shown in Fig. 2 and reduced rates of NEP during recovery, the stand reached $C$ neutrality after 3 years, and then began to accumulate $C$ at pre-burn levels. Simulations using BiomBGC also indicated that NEP would recover rapidly following prescribed burns in oak-dominated and mixed pine-oak stands, reaching $C$ neutrality in 2 and 3 years, respectively (Miao et al., 2011; Fig. 5). In simulations by Miao et al. (2011), an oak-dominated stand recovered more rapidly from dormant-season prescribed burns than mixed or pine-dominated stands, likely because of lower flame lengths and less consumption of forest floor, and minimal crown scorch in the oak-dominated stand. More intense prescribed fires will likely result in longer recovery times, especially in conifer-dominated stands with longer leaf life-spans. For example, PnET CN simulations for Jack pine (Pinus banksiana Lamb.) stands suggest that increased crowning fire frequency would result in lower NEP and NPP (Peters et al., 2013). The rapid recovery following prescribed fires described above contrasts somewhat with results reported by Whelan et al. (2013), who observed that half-hourly NEP in mesic, intermediate and xeric longleaf pine (Pinus palustris Mill.) stands recovered to pre-burn levels within 2 months of prescribed burns, but annual NEP values indicated that only the mesic stand sequestered $\mathrm{C}$, while the intermediate and xeric stands lost $\mathrm{C}$. It is notable that extreme drought affected NEP rates in all three stands in the years following the prescribed burns reported by Whelan et al. (2013). Following prescribed fires in pine and pineoak stands, evapotranspiration rates also recovered rapidly, with Et during the growing season representing $82 \%$ of pre-burn values the year of the burn, and then similar to pre-burn periods in the following years (Table 3; Clark et al., 2012). Rapid recovery of Et also occurred following prescribed burns in the longleaf pine stands, with annual values reduced only during the first year following fires (G. Starr, pers. comm.). In the pine - scrub oak stand shown in Figs. 3, 4b and 5, ecosystem water use efficiency (WUE $\mathrm{W}_{\mathrm{e}}$ defined as GEP/Et during dry canopy conditions) in the summer increased slightly, likely due to a fertilizer effect from the pyromineralization of the forest floor and understory vegetation (Boerner et al., 1988; Gray and Dighton, 2006; Renninger et al., 2013). For example, Boerner et al. (1988) show higher foliar phosphorus and calcium contents in white oak (Quercus alba L.) and chestnut oak (Quercus prinus L.) following prescribed burning relative to unburned individuals. Renninger et al. (2013) observed that prescribed burning resulted in higher photosynthetic rates, greater productivity, and greater water use efficiency of overstory pitch pine compared to unburned control trees.

Recovery from prescribed burns and wildfires will likely be affected by increased atmospheric $\mathrm{CO}_{2}$ concentrations and $\mathrm{N}$ deposition in the mid-Atlantic, in addition to changes in climate in the future. Using PnET CN to simulate forest productivity in the region, Pan et al. (2009) suggest that increases in $\mathrm{CO}_{2}$ and $\mathrm{N}$ deposition have stimulated forest productivity to a greater extent than changes in climate only. When changes to climate only were simulated, productivity of oak-hickory forests increased slightly with greater precipitation. In pine-dominated forests on less fertile soils, little effect on productivity with increased precipitation was noted, because although gross primary production (GPP) was enhanced, increased temperatures both at night and during the winter increased respiration rates. In contrast, interactions between climate, higher $\mathrm{CO}_{2}$ and enhanced $\mathrm{N}$ deposition increased NEP and NPP in all forest types in the mid-Atlantic (Pan et al., 2009). Empirical data suggests that $\mathrm{CO}_{2}$ stimulates recovery following fire, but a full factorial experiment with $\mathrm{CO}_{2}$ and nutrient enrichment remains to be conducted. For example, when slash pine (Pinus elliottii Engelm.) scrub oak stands were burned and then allowed to regenerate under either ambient or elevated atmospheric $\mathrm{CO}_{2}$ conditions, elevated $\mathrm{CO}_{2}$ increased aboveground biomass production, with the most gains observed for dominant species compared to subdominant species (Dijkstra et al., 2002), and accelerated the development of fine roots (Day et al., 2006; Dijkstra et al., 2002). Because changes in $\mathrm{C}$ dynamics with elevated $\mathrm{CO}_{2}$ are strongly influenced by $\mathrm{N}$ availability, low $\mathrm{N}$ sites may show only limited increases in growth in elevated $\mathrm{CO}_{2}$ environments (Oren et al., 2001; McCarthy et al., 2010), while elevated $\mathrm{CO}_{2}$ in concert with higher $\mathrm{N}$ deposition have led to increases in photosynthetic capacity and increased tree growth (Hyvönen et al., 2007; McCarthy et al., 2010). With relatively high $\mathrm{N}$ availability, stands can display greater overstory leaf area and an overall increase in NPP (McCarthy et al., 2010; Schäfer et al., 2003). Simulations and empirical results indicate that recovery from prescribed fires may be accelerated in the future, but will likely be dependent upon continued atmospheric deposition rates of $\mathrm{N}$ in the region. It is also possible that where prescribed fires are conducted frequently in sites with low $\mathrm{N}$ availability, volatilization of $\mathrm{N}$ from the litter layer and soil may exacerbate $\mathrm{N}$ limitation and alter patterns of $\mathrm{C}$ allocation (Tuininga and Dighton, 2004; Williams et al., 2012), such that trees may allocate 
more $\mathrm{C}$ belowground in order to increase $\mathrm{N}$ uptake (Schäfer et al., 2003; Palmroth et al., 2006; Hyvönen et al., 2007; Franklin et al., 2009), potentially reducing rates of fuel accumulation. Taken together, these studies suggest that recovery following prescribed burns will continue to be relatively rapid in the mid-Atlantic region, but also demonstrate some of the uncertainty that exists in attempting to predict potential outcomes of prescribed fire use with climate change, increased $\mathrm{CO}_{2}$ levels and $\mathrm{N}$ deposition scenarios as stands age.

Over longer time scales, model simulations using the LANDIS-II model coupled with CENTURY and the Dynamic Fire and Dynamic Biomass Fuels extensions to estimate forest $C$ sequestration in the $\mathrm{NJ}$ Pinelands suggest that fire management may have little impact on forest C dynamics (Scheller et al., 2011). Scheller et al. (2011) simulated three fire management scenarios over a 100 -year period; contemporary management as reflected in the recent (1991-2006) fire records, an increase in fire ignitions within WUI areas to simulate a doubling of the current area burned in prescribed fires, and longer response times to wildfires, reflecting a more liberal wildland fire use policy. Initial model simulations of monthly NEP were consistent with measurements at three carbon flux towers in the $\mathrm{NJ}$ Pinelands (Clark et al., 2010a; $r^{2}=0.89, P<0.001$ ). Under all scenarios, model simulations suggest that forests in the study area would continue to accumulate $C$ over the next 100 years, under current climatic conditions. Although aboveground NPP, live biomass, and detrital $C$ were predicted to be nearly constant or increase only modestly, soil organic $C$ continued to increase through time in all forest types except the most frequently-burned pitch pine - scrub oak stands, consistent with the observations of Williams et al. (2012). Scheller et al. (2011) point out that simulated changes in management strategies represent only minor alterations to the fire regime, thus fire management may have only minor effects on regional forest $C$ budgets in the immediate future, particularly when compared to the effects of recovery from large-scale historic disturbances (e.g., Pan et al., 2009, 2011). Further simulations using the HadCM3 A2 emission scenario with LANDIS II and CENTURY indicate that the rate of $C$ storage in detrital $C$ and soil organic matter will decrease through time because of higher heterotrophic respiration rates (Scheller et al., 2012). This implies greater rates of litter decomposition and a reduction in the rate of fuel accumulation on the forest floor through time (Piatek et al., 2010), potentially further reducing wildfire activity.

Wildfire risk in the mid-Atlantic could increase with the conversion of naturally regenerated forest and agricultural lands to shortrotation pine plantations as a potential climate change mitigation strategy (Kobziar et al., 2009; Thompson et al., 2011). Young pine stands are highly productive, with short-rotation stands further south on the Atlantic coastal plain and Piedmont characterized by some of the highest NPP and NEP rates measured to date (Bracho et al., 2012; Masek and Collatz, 2006; Noormets et al., 2010, 2012). Fuel reduction treatments are rarely conducted in stands managed for pulpwood or fiber. Large-scale conversion to short-rotation forests for fiber, biofuels or other uses could result in greater occurrence and severity of wildfires, similar to the wildfire-prone industrial forests of the late 1800's and early 1900's (e.g., Brose et al., 2013a; Forman and Boerner, 1981). Changing vegetation types due to forest management also has implications for other ecosystem services, because "dormant" season Et in pine dominated stands is greater, resulting in a higher annual Et in pine-dominated stands (mean of $770 \mathrm{~mm}$ year $^{-1}$ ) when compared to hardwood-dominated stands (mean of $664 \mathrm{~mm} \mathrm{year}^{-1}$; reviewed in Clark et al. (2012)). Pine-dominated forests also had a lower $W_{U} E_{e}$ during the summer growing season compared to oak-dominated stands (Clark et al., pers. comm.), and thus used water less efficiently for $C$ uptake. Thus, land managers will need to evaluate the trade-offs between $C$ sequestration, wildfire, and water resources when considering large-scale forest conversions. This is already occurring to some extent in the southern mid-Atlantic, where there has been an increasing trend towards the conversion of naturally regenerated forests to short-rotation pine plantations in Virginia, but acreage of plantation forests are stable in New Jersey, and decreasing in New York from a maximum in the 1930-1970's.

\section{Conclusions}

There is little evidence to suggest that current wildfire regimes will be dramatically altered from the present, given projections of future climate scenarios in the mid-Atlantic region. Current trends in forest regeneration, complex spatial patterns of land use, land ownership, and forest fragmentation, and fire suppression and fuels management activities will likely continue to constrain wildfire occurrence and severity in the future. Prescribed burning is the most cost-effective forest management technique for reducing hazardous fuels and mitigating the ecological impacts of changing fire regimes. Field research and simulation studies suggest that prescribed burning in wildfire prone areas in the mid-Atlantic does not significantly impact short- or long-term $C$ sequestration at either stand or landscape scales, and in concert with fire suppression activities, likely reduces the $C$ losses associated with wildfires in wildfire-prone areas. However, it will be difficult to reintroduce fire into many of the forested ecosystems in the mid-Atlantic on a large scale without major effort, because patterns of land ownership, increasing WUI, legal liability issues, and local, state and federal air quality regulations will further constrain the use of prescribed burning in the future. Unlike the Western US, state and federally-owned lands total less than $21 \%$ of forested lands in the mid-Atlantic, and public perception of wildland fire use may have to change drastically. Future mitigation strategies aimed at increasing $C$ sequestration and/or biofuel production will need to balance fire risk and public safety, water resources, and other ecosystem services across the region.

\section{References}

Abrams, M.D., 2003. Where has all the white oak gone? BioScience 53, 927-939.

Agee, J.K., Skinner, C.N., 2005. Basic principles of forest fuel reduction treatments Forest Ecol. Manage. 211, 83-96.

Amiro, B.D., Barr, A.G., Barr, J.G., Black, T.A., Bracho, R., Brown, M., Chen, J., Clark, K.L., Davis, K.J., Desai, A.R., Dore, S., Engel, V., Fuentes, J.D., Goulden, M.L., Kolb, T.E., Lavigne, M.B., Law, B.E., Margolis, H.A., Martin, T., McCaughey, J.H., MontesHelu, M., Noormets, A., Randerson, J.T., Starr, G., Xiao, J., 2010. Ecosystem carbon dioxide fluxes after disturbance in forests of North America. J. Geophys. Res. 115, G00K02. http://dx.doi.org/10.1029/2010JG001390.

Anderson, B.T., Hayhoe, K., Liang, X., 2010. Anthropogenic-induced changes in twenty-first century summertime hydroclimatology of the Northeastern US Clim. Change 99, 403-423.

Arthur, M.A., Alexander, H.D., Dey, D.C., Schweitzer, C.J., Loftis, D.L., 2012. Refining the oak-fire hypothesis for management of oak-dominated forests of the eastern United States. J. Forest., 257-266.

Boerner, R.E., Lord, T.R., Peterson, J.C., 1988. Prescribed burning in the oak-pine forest of the New Jersey Pine Barrens: effects on growth and nutrient dynamics of two Quercus species. Am. Midl. Nat., 108-119.

Boerner, R.E.J., Huang, J., Hart, S.C., 2008. Fire, thinning, and the carbon economy: effects of the fire and fire surrogate treatments on estimated carbon storage and sequestration rate. Forest Ecol. Manage. 255, 3081-3097.

Boerner, R.E.J., Huang, J., Hart, S.C., 2009. Impacts of fire and fire surrogate treatments on forest soil properties: a meta-analytical approach. Ecol. Appl. 19, 338-358.

Bracho, R., Starr, G., Gholz, H.L., Martin, T.A., Cropper Jr., W.P., Loescher, H.W., 2012 Controls on carbon dynamics by ecosystem structure and climate for southeastern US slash pine plantations. Ecol. Monogr. 82, 101-128.

Brose, P.H., 2009. Photo guide for estimating fuel loading and fire behavior in mixed-oak forests of the Mid-Atlantic Region. In: Forest Service Gen. Tech. Rep. NRS-45, US Department of Agriculture.

Brose, P.H., 2010. Long-term effects of single prescribed fires on hardwood regeneration in oak shelterwood stands. Forest Ecol. Manage. 260, 1516-1524.

Brose, P.H., Dey, D.C., Guyette, R.P., Marschall, J.P., Stambaugh, M.C., 2013a. The influences of drought and humans on the fire regimes of northern Pennsylvania, USA. Can. J. Forest Res., 0.1139/cjfr-2012-0463. 
Brose, P.H., Dey, D.C., Phillips, R.J., Waldrop, T.A., 2013b. A meta-analysis of the fireoak hypothesis: does prescribed burning promote oak reproduction in eastern North America. For. Sci. 59, 322-334.

Buchanan, M.L., Hart, J.L., 2012. Canopy disturbance history of old-growth Quercus alba sites in the eastern United States: examination of long-term trends and broad-scale patterns. Forest Ecol. Manage. 267, 28-39.

Burton, J.A., Hallgren, S.W., Fuhlendorf, S.D., Leslie Jr., D.M., 2011. Understory response to varying fire frequencies after 20 years of prescribed burning in an upland oak forest. Plant Ecol. 212, 1513-1525.

Chiang, J.M., McEwan, R.W., Yaussy, D.A., Brown, K.J., 2008. The effects of prescribed fire and silvicultural thinning on the aboveground carbon stocks and net primary production of overstory trees in an oak-hickory ecosystem in southern Ohio. Forest Ecol. Manage. 255, 1584-1594.

Clark, K.L., Skowronski, N., Hom, J., Duveneck, M., Pan, Y., Van Tuyl, S., Cole, J., Patterson, M., Maurer, S., 2009. Decision support tools to improve the effectiveness of hazardous fuel reduction treatments. Int. J. Wildland Fire 18, 268-277.

Clark, K.L., Skowronski, N., Gallagher, M., Heilman, W., Hom, J., 2010a. Fuel consumption and particulate emissions during fires in the New Jersey Pinelands. In: Proc. 3rd Fire Behavior and Fuels Conference, October 25-29, 2010, Spokane, Washington, USA

Clark, K.L., Skowronski, N., Hom, J., 2010b. Invasive insects impact forest carbon dynamics. Glob. Change Biol. 16, 88-101.

Clark, K.L., Skowronski, N., Gallagher, M., Renninger, H., Schäfer, K., 2012. Effects of invasive insects and fire on forest energy exchange and evapotranspiration in the New Jersey Pinelands. Agric. For. Meteorol. 166-167, 50-61.

Day, F.P., Stover, D.B., Pagel, A.L., Hungate, B.A., Dilustro, J.J., Herbert, B.T., Drake, B.G., Hinkle, C.R., 2006. Rapid root closure after fire limits fine root responses to elevated atmospheric $\mathrm{CO}_{2}$ in a scrub oak ecosystem in central Florida, USA. Glob. Change Biol. 12, 1047-1053.

Dijkstra, P., Hymus, G., Colavito, D., Vieglais, D.A., Cundari, D.M., Johnson, D.P. Hungate, B.A., Hinkle, C.R., Drake, B.G., 2002. Elevated atmospheric $\mathrm{CO}_{2}$ stimulates aboveground biomass in a fire-regenerated scrub-oak ecosystem. Glob. Change Biol. 8, 90-103.

Drummond, M.A., Loveland, T.R., 2010. Land-use pressure and a transition to forestcover loss in the Eastern United States. BioScience 60, 286-298.

Fan, Z., Ma, Z., Dey, D.C., Roberts, S.D., 2012. Response of advance reproduction of oaks and associated species to repeated prescribed fires in upland oak-hickory forests, Missouri. Forest Ecol. Manage. 266, 160-169.

Forman, R.T.T., Boerner, R., 1981. Fire frequency and the Pine Barrens of New Jersey. Bull. Torrey Bot. Club 108, 34-50.

Franklin, O., McMurtrie, R.E., Iversen, C.M. Crous, KY, Finzi, A.C. Tissue, D.T., Ellsworth, D.S., Oren, R., Norby, R.J., 2009. Forest fine-root production and nitrogen use under elevated $\mathrm{CO}_{2}$ : contrasting responses in evergreen and deciduous trees explained by a common principle. Glob. Change Biol. 15, 132-144.

French, N.H., de Groot, W.J., Jenkins, L.K., Rogers, B.M., Alvarado, E., Amiro, B. Turetsky, M., 2011. Model comparisons for estimating carbon emissions from North American wildland fire. J. Geophys. Res.: Biogeosci. (2005-2012) 116 (G4).

Graham, J.B., McCarthy, B.C., 2006. Forest floor fuel dynamics in mixed-oak forests of south-eastern Ohio. Int. J. Wildland Fire 15, 479-488.

Gray, D.M., Dighton, J., 2006. Mineralization of forest litter nutrients by heat and combustion. Soil Biol. Biochem. 38, 1469-1477.

Gray, D.M., Dighton, J., 2009. Nutrient utilization by pine seedlings and soil microbes in oligotrophic pine barrens forest soils subjected to prescribed fire treatment. Soil Biol. Biochem. 41, 1957-1965.

Grima, P.P., 2009. Determination of springtime foliar moisture content in Pitch Pine (Pinus rigida). MA Thesis, University of Mass.

Hartman, G.W., 2004. Changes in fuel loadings as the result of repeated prescribed fires within the Ozark forests of Missouri. In: Yaussy, D.A., Hix, D.M., Long, R.P., Goebel, P.C. (Eds.), Proceedings of the 14th Central Hardwood Forest Conference. General Technical Report NE-316, US Department of Agriculture, Forest Service, Northeastern Research Station, Newtown Square, pp. 162-167.

Hawbaker, T.J., Radeloff, V.C., Stewart, S.I., Hammer, R.B., Keuler, N.S., Clayton, M.K., 2013. Human and biophysical influences on fire occurrence in the United States. Ecol. Appl. 23, 565-582.

He, L., Chen, J.M., Pan, Y., Birdsey, R., Kattge, J., 2012. Relationships between net primary productivity and forest stand age in US forests. Glob. Biogeochem. Cycles 26, GB3009. http://dx.doi.org/10.1029/2010GB003942.

Heilman, W.E., Bian, X., 2010. Turbulent kinetic energy during wildfires in the north central and north-eastern US. Int. J. Wildland Fire 19, 346-363.

Hessl, A.E., 2011. Pathways for climate change effects on fire: models, data, and uncertainties. Prog. Phys. Geogr. 35, 393-407.

Hicke, J.A., Allen, C.D., Desai, A.R., Dietze, M.C., Hall, R.J., Kashian, D.M., Moore, D., Raffa, K.F., Sturrock, R.N., Vogelmann, J., 2012. Effects of biotic disturbances on forest carbon cycling in the United States and Canada. Glob. Change Biol. 18, 7-34.

Hubbard, R.M., Vose, J.M., Clinton, B.D., Elliott, K.J., Knoepp, J.D., 2004. Stand restoration burning in oak-pine forests in the southern Appalachians: effects on aboveground biomass and carbon and nitrogen cycling. Forest Ecol. Manage. $190,311-321$.

Hutchinson, T.F., Sutherland, E.K., Yaussy, D.A., 2005. Effects of repeated prescribed fires on the structure, composition, and regeneration of mixed-oak forests in Ohio. Forest Ecol. Manage. 218, 210-228.

Hutchinson, T.F., Yaussy, D.A., Long, R.P., Rebbeck, J., Sutherland, E.K., 2012. Longterm (13-year) effects of repeated prescribed fires on stand structure and tree regeneration in mixed-oak forests. Forest Ecol. Manage. 286, 87-100.
Hyvönen, R., Àgren, G.I., Linder, S., Persson, T., Contrufo, M.F., Ekblad, A., Freeman, M., Grelle, A., Janssens, I.A., Jarvis, P.G., Kellomäki, S., Lindroth, A., Loustau, D. Lundmark, T., Norby, R.J., Oren, R., Pilegaard, K., Ryan, M.G., Sigurdsson, B.D., Strömgren, M., van Oijen, M., Wallin, G., 2007. The likely impact of elevated $\mathrm{CO}_{2}$, nitrogen deposition, increased temperature and management on carbon sequestration in temperate and boreal forest ecosystems: a literature review. New Phytol. 173, 463-480.

Jenkins, J.C., Birdsey, R.A., Pan, Y., 2001. Biomass and NPP estimation for the midAtlantic region (USA) using plot-level forest inventory data. Ecol. Appl. 11, 1174-1193.

Jordan, M.A., Patterson III, W.A., Windisch, A.G., 2003. Conceptual ecological models for the Long Island Pitch Pine Barrens. Forest Ecol. Manage. 185, 151-168.

Kasischke, E.S., Amiro, B.D., Barger, N.N., French, N.H.F., Goetz, S.J., Grosse, G., Harmon, M.E., Hicke, J.A., Liu, S., Masek, J.G., 2013. Impacts of disturbance on the terrestrial carbon budget of North America. J. Geophys. Res. Biogeosci. 118 , 303-316. http://dx.doi.org/10.1002/jgrg.20027.

Keane, R.E., 2013. Describing wildland surface fuel loading for fire management: a review of approaches, methods, and systems. Int. J. Wildland Fire 22, 51-62.

Kobziar, L.N., McBride, J.R., Stephens, S.L., 2009. The efficacy of fire and fuels reduction treatments in a Sierra Nevada pine plantation. Int. J. Wildland Fire 18, 791-801.

Kreye, J., Varner, J.M., Hiers, J.K., Mola, J., 2013. Toward a mechanism for eastern North American forest mesophication: differential litter drying across 17 species. Ecol. Appl., <http://www.dx.doi.org/10.1890/13-0503.1>

Lafon, C.W., Quiring, S.M., 2012. Relationships of fire and precipitation regimes in temperate forests of the Eastern United States. Earth Interact. 16, 1-15.

Little, S., 1979. Fire and plant succession in the New Jersey pine barrens. In: Foreman, R.T.T. (Ed.), Pine Barrens: Ecosystem and Landscape. Academic Press, New York, NY, pp. 297-314.

Little, S., Moore, E.B., 1949. The ecological role of prescribed burns in the pine-oak forests of southern New Jersey. Ecology 30, 223-233.

Liu, Y., Goodrick, S.L., Stanturf, J.A., 2013. Future US wildfire potential trends projected using a dynamically downscaled climate change scenario. Forest Ecol. Manage. 294, 120-133.

Loehman, R.A., Reinhardt, E., Riley, K.L., 2014. Wildland fire emissions, carbon, and climate: seeing the forest and the trees - A cross-scale assessment of wildfire and carbon dynamics in fire-prone, forested ecosystems. Forest Ecol. Manage. 317, 9-19.

Lutes, D.C., Keane, R.E., Caratti, J.F., 2009. A surface fuel classification for estimating fire effects. Int. J. Wildland Fire 18, 802-814.

Masek, J.G., Collatz, G.J., 2006. Estimating forest carbon fluxes in a disturbed southeastern landscape: integration of remote sensing, forest inventory, and biogeochemical modeling. J. Geophys. Res. 111, G01006. http://dx.doi.org/ 10.1029/2005JG000062.

McCarthy, H.R., Oren, R., Johnson, K.H., Gallet-Budynek, A., Pritchard, S.G., Cook, C.W., LaDeau, S.L., Jackson, R.B., Finzi, A.C., 2010. Re-assessment of plant carbon dynamics at the Duke free-air $\mathrm{CO}_{2}$ enrichment site: interactions of atmospheric $\left[\mathrm{CO}_{2}\right]$ with nitrogen and water availability over stand development. New Phytol. $185,514-528$.

Medvigy, D., Clark, K.L., Skowronski, N.S., Schäfer, K.V.R., 2012. Simulated impacts of insect defoliation on forest carbon dynamics. Environ. Res. Lett. 7 (4), 045703.

Miao, Z., Lathrop Jr., R.G., Xu, M., La Puma, I.P, Clark, K.L., Hom, J., Skowronski, N., Van Tuyl, S., 2011. Simulation and sensitivity analysis of carbon storage and fluxes in the New Jersey Pinelands. Environ. Mod. Soft.. http://dx.doi.org/ 10.1016/j.envsoft.2011.03.004.

Morton, D.C., Collatz, G.J., Wang, D., Randerson, J.T., Giglio, L., Chen, Y., 2013. Satellite-based assessment of climate controls on US burned area. Biogeosciences 10, 247-260.

Nave, L.E., Vance, E.D., Swanston, C.W., Curtis, P.S., 2011. Fire effects on temperate forest soil C and N storage. Ecol. Appl. 21, 1189-1201.

Neill, C., Patterson III, W.A., Crary Jr., D.W., 2007. Responses of soil carbon, nitrogen and cations to the frequency and seasonality of prescribed burning in a Cape Cod oak-pine forest. Forest Ecol. Manage. 250, 234-243.

New Jersey Forest Fire Service, 2006. Section Forest Fire Wardens of Division B. Images of America: New Jersey Forest Fire Service. Arcadia Publishing, p. 127.

NIFC. 2013. National Interagency Fire Center, Boise, ID. <http://www.nifc.gov/ fireinfo/fireinfo_statistics.html>

Noormets, A., Gavazzi, M.G., McNulty, S.G., Domec, J.-C., Sun, G., King, J.S., Chen, J., 2010. Response of carbon fluxes to drought in a coastal plain loblolly pine forest. Glob. Change Biol. 16, 272-287.

Noormets, A., McNulty, S.G., Domec, J.C., Gavazzi, M., Sun, G., King, J.S., 2012. The role of harvest residue in rotation cycle carbon balance in loblolly pine plantations. Respiration partitioning approach. Glob. Change Biol. 18 (10), 3186-3201.

Nowacki, G.J., Abrams, M.D., 2008. The demise of fire and "mesophication" of forests in the Eastern United States. BioScience 58, 123-138.

Nuttle, T., Royo, A.A., Adams, M.B., Carson, W.P., 2013. Historic disturbance regimes promote tree diversity only under low browsing regimes in eastern deciduous forest. Ecol. Monogr. 83, 3-17.

Oren, R., Ellsworth, D.S., Johnsen, K.H., Phillips, N., Ewers, B.E., Maier, C.A., Schäfer, K.V.R., McCarthy, H.R., Hendrey, G., McNulty, S.G., Katul, G.G., 2001. Soil fertility limits carbon sequestration by forest ecosystems in a $\mathrm{CO}_{2}$ enriched atmosphere. Nature 411, 469-472.

Ottmar, R.D., Sandberg, D.V., Riccardi, C.L., Prichard, S.J., 2007. An overview of the fuel characteristic classification system-quantifying, classifying, and creating fuelbeds for resource planning. Can. J. For. Res. 37, 2383-2393. 
Palmroth, S., Oren, R., McCarthy, H.R., Johnsen, K.H., Finzi, A.C., Butnor, J.R., Ryan, M.G. Schlesinger, W.H., 2006. Aboveground sink strength in forests controls the allocation of carbon below ground and its $\left[\mathrm{CO}_{2}\right]$-induced enhancement. Proc. Natl. Acad. Sci., USA 103, 19362-19367.

Pan, Y., Hom, J., Jenkins, J., Birdsey, R., 2004. Importance of foliar nitrogen concentration to predict forest productivity in the mid-atlantic region. For Sci. 50, 279-289.

Pan, Y., Birdsey, R., Hom, J., McCullough, K., Clark, K., 2006. Improved estimates of net primary productivity from MODIS satellite data at regional and local scales Ecol. Appl. 16, 125-132.

Pan, Y., Birdsey, R., Hom, J., McCullough, K., 2009. Separating effects of changes in atmospheric composition, climate and land-use on carbon sequestration of US Mid-Atlantic temperate forests. Forest Ecol. Manage. 259, 151-164.

Pan, Y., Chen, J.M., Birdsey, R., McCullough, K., He, L., Deng, F., 2011. Age structure and disturbance legacy of North American forests. Biogeoscience 8, 715-732.

Peters, E.B., Wythers, K.R., Bradford, J.B., Reich, P.B., 2013. Influence of disturbance on temperate forest productivity. Ecosystems 16, 95-110.

Phillips, R.J., Waldrop, T.A., Brose, P. H., Wang, G.G., 2012. Restoring fire-adapted forests in Eastern North America for biodiversity conservation and hazardous fuels reduction. In: Stanturf, J., et al. (Eds.), A Goal-Oriented Approach to Forest Landscape Restoration, World Forests, vol. 16, pp. 187-219, doi: 10.1007/978 94-007-5338-9.

Piatek, K.B., Munasinghe, P., Peterjohn, W.T., Adams, M.B., Cumming, J.R., 2010. A decrease in oak litter mass changes nutrient dynamics in the litter layer of a central hardwood forest. North. J. Appl. For. 27, 97-104.

Pollina, J.B., Colle, B.A., Charney, J.J., 2013. Climatology and meteorological evolution of major wildfire events over the Northeast United States. Weather Forecast. 28 175-193.

Polo, J.A., Hallgren, S.W., Leslie Jr., D.M., 2013. Effect of long-term understory prescribed burning on standing and down dead woody material in dry upland oak forests. Forest Ecol. Manage. 291, 128-135.

Potter, B.E., 2012. Atmospheric interactions with wildland fire behaviour-I - basic surface interactions, vertical profiles and synoptic structures. Int. J. Wildland Fire.

Prasad, A.M., Iverson, L.R., Matthews, S., Peters, M., 2011-ongoing. A Climate Change Atlas for 134 Forest Tree Species of the Eastern United States, US Department of Agriculture, Forest Service. <http://www.nrs.fs.fed.us/atlas/tree>.

Reich, P.B., 2012. Key canopy traits drive forest productivity. Proc. Roy. Soc. B 279 $2128-2134$.

Renninger, H.J., Clark, K.L., Skowronski, N., Schäfer, K.V.R., 2013. Effects of a prescribed burn on the water use and photosynthetic capacity of pitch pines (Pinus rigida) in the New Jersey Pine Barrens. Trees. http://dx.doi.org/10.1007/s 00468-013-0861-5.

Rollins, M.G., 2009. LANDFIRE: a nationally consistent vegetation, wildland fire, and fuel assessment. Int. J. Wildland Fire 18 (3), 235-249.

Royse, J., Arthur, M.A., Schörgendorfer, A., Loftis, D.L., 2010. Establishment and growth of oak (Quercus alba, Quercus prinus) seedlings in burned and fireexcluded upland forests on the Cumberland Plateau. Forest Ecol. Manage. 260, 502-510.

Ryan, K.C., Knapp, E.E., Varner, J.M., 2013. Prescribed fire in North American forests and woodlands: history, current practice, and challenges. Front. Ecol. Environ. 11, e15-e24, <http://www.dx.doi.org/10.1890/120329>.

Schäfer, K.V.R., Oren, R., Ellsworth, D.S., Lai, C.T., Herrick, J.D., Finzi, A.C., Richter D.D., Katul, G.G., 2003. Exposure to an enriched $\mathrm{CO}_{2}$ atmosphere alters carbon assimilation and allocation in a pine forest ecosystem. Glob. Change Biol. 9, 1378-1400.

Scheller, R.M., Van Tuyl, S., Clark, K.L., Hom, J., La Puma, I., 2011. Carbon sequestration in the New Jersey pine barrens under different scenarios of fire management. Ecosystems. http://dx.doi.org/10.1007/s10021-011-9462-6.

Scheller, R.M., Kretchun, A.M., Van Tuyl, S., Clark, K.L., Lucash, M.S., Hom, J., 2012. Divergent carbon dynamics under climate change in forests with diverse soils, tree species, and land use histories. Ecosphere 3, 110.
Scott, J.H., Burgan, R.E., 2005. Standard fire behavior fuel models: a comprehensive set for use with Rothermel's surface fire spread model. In: USDA For. Serv. Gen. Tech. Rep. RMRS-GTR-153.

Skowronski, N., Clark, K., Nelson, R., Hom, J., Patterson, M., 2007. Remotely sensed measurements of forest structure and fuel loads in the Pinelands of New Jersey. Remote Sens. Environ. 108, 123-129.

Skowronski, N.S., Clark, K.L., Duveneck, M., Hom, J., 2011. Three-dimensional canopy fuel loading predicted using upward and downward sensing LIDAR systems. Remote Sens. Environ. 115, 703-714.

Spracklen, D.V., Mickley, L.J., Logan, J.A., Hudman, R.C., Yevich, R., Flannigan, M.D., Westerling, A.L., 2009. Impacts of climate change from 2000 to 2050 on wildfire activity and carbonaceous aerosol concentrations in the western United States. J. Geophys. Res. 114, D20301. http://dx.doi.org/10.1029/2008JD010966.

Stephens, S.L., McIver, J.D., Boerner, R.E., Fettig, C.J., Fontaine, J.B., Hartsough, B.R., Kennedy, P.L., Schwilk, D.W., 2012. The effects of forest fuel-reduction treatments in the United States. BioScience 62, 549-560.

Sturtevant, B.R., Scheller, R.M., Miranda, B.R., Shinneman, D., 2009. Simulating dynamic and mixed severity fire regimes: a process-based fire extension for LANDIS-II. Ecol. Model. 220, 3380-3393.

Thompson, J.R., Spies, T.A., Olsen, K.A., 2011. Canopy damage to conifer plantations within a large mixed-severity wildfire varies with stand age. For. Ecol. Manage 262, 355-360.

Tuininga, A.R., Dighton, J., 2004. Changes in ectomycorrhizal communities and nutrient availability following prescribed burns in two upland pine oak forests in the New Jersey pine barrens. Can. J. Forest Res. 34 (8), 1755-1765.

Urbanski, S., 2014. Wildland fire emissions, carbon, and climate: emission factors Forest Ecol. Manage. 317, 51-60.

Vanderwel, M.C., Coomes, D.A., Purves, D.W., 2013. Quantifying variation in forest disturbance, and its effects on aboveground biomass dynamics, across the eastern United States. Glob. Change Biol. 19, 1504-1517.

Waldrop, T.A., Brudnak, L., Rideout-Hanzak, S., 2007. Fuels on disturbed and undisturbed sites in the southern Appalachian Mountains, USA. Can. J. For. Res. 37, 1134-1141.

Waldrop, T.A., Phillips, R.J., Simon, D.A., 2010. Fuels and predicted fire behavior in the southern Appalachian Mountains after fire and fire surrogate treatments. For. Sci. 56, 32-45

Wang, Q., Zhong, M., Wang, S., 2012. A meta-analysis on the response of microbial biomass, dissolved organic matter, respiration, and $\mathrm{N}$ mineralization in minera soil to fire in forest ecosystems. Forest Ecol. Manage. 271, 91-97.

Weise, D.R., Wright, C.S., 2014. Wildland fire emissions, carbon and climate: characterizing wildland fuels. For. Ecol. Manage. 317, 26-40.

Westerling, A.L., Hidalgo, H.G., Cayan, D.R., Swetnam, T.W., 2006. Warming and earlier spring increase western US forest wildfire activity. Science 313, 940 943.

Whelan, A., Mitchell, R., Staudhammer, C., Starr, G., 2013. Cyclic occurrence of fire and its role in carbon dynamics along an edaphic moisture gradient in longleaf pine ecosystems. PloS One 8 (1), e54045.

Williams, R.J., Hallgren, S.W., Wilson, G.W., 2012. Frequency of prescribed burning in an upland oak forest determines soil and litter properties and alters the soil microbial community. Forest Ecol. Manage. 265, 241-247.

Woodall, C.W., Zhu, K., Westfall, J.A., Oswalt, C.M., D’Amato, A.W., Walters, B.F., Lintz, H.E., 2013. Assessing the stability of tree ranges and influence of disturbance in eastern US forests. Forest Ecol. Manage. 291, 172-180.

Wotton, B.M., Nock, C.A., Flannigan, M.D., 2010. Forest fire occurrence and climate change in Canada. Int. J. Wildland Fire 19, 253-271.

Wright, C.S., Ottmar, R.D., Vihnanek, R.E., 2007. Stereo Photo Series For Quantifying Natural Fuels, Volume VIII: Hardwood, Pitch Pine, and Red Spruce/Balsam Fir Types in the Northeastern United States. National Wildfire Coordinating Group, National Interagency Fire Center, Boise, ID, p. 91. 